\title{
Economics of Rice Production in Mubi-North Local Government Area of Adamawa State-Nigeria
}

\author{
Madugu, A.J.*, Moses, J.D.* and Zalkuwi, J.W.* \\ * Department of Agricultural Economics \& Extension., Adamawa State University, Mubi, Nigeria.
}

\begin{abstract}
This study investigated the profitability of rice production in Mubi-North Local Government Area of Adamawa State. Specifically, input-output relationship and resource use efficiency were determined. Structured questionnaires were used to collect data from 100 rice farmers using simple random sampling technique from Mubi, Mayo-Bani, Ba'a, and Fali districts of Mubi-North LGA. Analytical tools used were descriptive statistics, gross margin analysis, multiple regression, and efficiency of resource use. The result showed a profit of $\$ 16$, 977.65 indicating that it is worthwhile to invest in rice production in the study area. Regression analysis revealed an $R^{2}$ of $79.6 \%, f$-value of 53.982 and standard error of 350.047. The result also revealed that land, seed, hired labour, and fertilizer were significant at different levels indicating that they were the major determinants of rice output in the area. Furthermore, the efficiency of resource use revealed that land; seeds, hired labour, and fertilizer were underutilized while chemicals and family labour were over utilized. However, all inputs were not utilized to optimum economic advantage. The study concluded that it was profitable to invest in rice production, and that there is a need for adjustment in the MVP of all the inputs to ensure optimal use.
\end{abstract}

Keywords: Resource use, Rice production, Adamawa, Mubi-North.

\section{Introduction}

Rice, oryza sativa is a seed of monocot plant from the family graminaceae with two main cultigens: sativa from Asia and glabarima from Africa (David, 1992). Its production started in Nigeria around the 1500BC with the low yielding indigenous specie oryza glabarima which was widely grown in the Niger-Delta area. By 1890 , oryza sativa was introduced into the country and accounted for more than $60 \%$ of the rice grown in the country. IRRI (1997) reported that rice is one of the oldest foods to man. It is the staple food of most countries of the world and its importance cannot be over-emphasized. It has risen from being a ceremonial food in most countries like Nigeria to form part of the daily diet and indeed an economic and political commodity.

Adebayo and Onu (1999) submitted that rice is one of the most important cereal crops grown in Adamawa State and is consumed in a variety of ways. They further emphasized that it is the most important cereal crop grown under rain-fed condition in the state but its cultivation is merely on a small-scale basis. It was reported by Akande (2002) that rice has risen to a position of pre-eminence; its consumption has tremendously risen since the mid 1970s. Due to changes in consumer preferences and increased population, domestic production has never been able to meet demand, leading to considerable imports standing at about 1,000,000 metric tonnes per annum and Nigeria spending over US $\$ 300$ million on imports alone annually (Moses and Adebayo, 2007). USDA (2003) also stated that Nigeria's imports in 2004 was projected at 1,000,000 metric tonnes thereby placing her as the largest rice importer in sub-Saharan Africa and one of the largest global rice importers after Indonesia.

Despite the availability of fertile land and good climate condition in the study area, there is still low productivity of rice to meet up with the growing population. Akpokodje et al (2001) further reported that a comprehensive and up to date picture of the rice production and processing sector was lacking. It is also a fact that most rice farmers in the state know very little about the economics of rice production as observed by Shehu et al (2009). This has led to drastic reduction in total output because farmers are not getting optimum returns from the resources committed to the enterprise.

The objective of the study was to evaluate the profitability of rice production in Mubi-North Local Government Area, Adamawa State; while specific objectives were to examine the socio-economic characteristics of rice farmers, to determine the input-output relationship in rice production and also to determine the resource use efficiency of rice production in the study area.

\section{Materials and Methods}

This study was conducted in Mubi-North Local Government Area of Adamawa State. Simple random sampling technique was used to distribute questionnaires to rice farmers in the four districts of the Local Government according to the proportion of producers found in each district i.e. 30 questionnaires each in Mubi and Mayo-Bani and 20 each in Ba'a and Fali districts respectively. 
Analytical tools used in the study involve the use of means and percentages to analyse the socio-economic characteristics. Others are -:

i. The gross margin analysis was used to determine the costs and returns associated with rice production in the study area. Following Okoruwa (1994) and Adebayo (2005), labour was converted to man hours factor of 1 for matured adult males, 0.75 for matured females, and 0.50 for young males. It was further converted to man day by dividing the man hour by 8 . The fixed cost considered was land. Gross margin can be obtained by the formula below-:

$$
\begin{aligned}
& G M=T R-T V C \\
& \text { Where GM }=\text { gross margin } \\
& \text { TR }=\text { total revenue } \\
& \text { TVC }=\text { total variable costs }
\end{aligned}
$$

TR includes revenue from sales of rice while TVC includes production costs such as cost of seeds, fertilizer, labour, chemicals, and storage. Others include cost of bagging, transportation, and land.

ii. Production function was used to determine the resource use efficiency. The general form of the model is given as-:

$$
\begin{aligned}
& Y=f(\left.X_{1}, X_{2}, X_{3}, X_{4}, X_{5}, X_{6}, U\right) \\
& \text { Where } Y=\text { rice output }(\mathrm{kg}) \\
& \mathrm{X}_{1}=\text { farm size }(\mathrm{Ha}) \\
& \mathrm{X}_{2}=\text { quantity of seed }(\mathrm{kg}) \\
& \mathrm{X}_{3}=\text { family labour (man days) } \\
& \mathrm{X}_{4}=\text { hired labour (man days) } \\
& \mathrm{X}_{5}=\text { fertilizer quantity }(\mathrm{kg}) \\
& \mathrm{X}_{6}=\text { chemicals }(\mathrm{l}) \\
& \mathrm{U}=\text { stochastic term }
\end{aligned}
$$

Linear, exponential, semi-log and double-log functions were tried. However, the linear function gave the best fit and was selected for analysis based on economic, statistical and econometric criteria. It is implicitly written as follows:

$$
Y=b_{1} X_{1}+b_{2} X_{2}+b_{3} X_{3}+b_{4} X_{4}+b_{5} X_{5}+b_{6} X_{6}+U
$$

$\mathrm{b}_{\mathrm{i}}=$ parameters estimated.

iii. Efficiency of resource use was determined based on the estimated production function using the following formulae:

$$
r=\frac{M V P}{M F C}
$$

Where $r=$ efficiency level

$$
\text { MVP = marginal value product }
$$

MFC = marginal factor cost

For the value of r: one (1) indicates efficient use of resources while less than or greater than is over use and under use respectively.

\section{Socio-Economic Characteristics of Rice Famers-:}

\section{Results and Discussion}

The socio-economic characteristics of rice farmers which include age, gender, literacy level, years of experience, and farm size are presented on Table I. Data showed that farmers between the ages of 41 and 50 had the highest percentage (49.0\%) followed by those between ages 31 and 40 years $(26.0 \%)$ and $21-30 \mathrm{yrs}(19.0 \%)$. It can be concluded that most of the farmers are in their economic active years.

The table further reveals that male respondents comprise of $(88.0 \%)$ while $(12.0 \%)$ goes for the females. This means that males participate more in rice production than their female counterparts in the study area. More than half the farmers (76.6\%) had some formal education and hence will possibly be innovative. This is substantiated by Dogondaji and Baba (2010) who observed that high literacy level could have positive impact on the adoption of Agricultural technologies.

Famers with experience of about $6-10 \mathrm{yrs}$ and above $15 \mathrm{yrs}$ constituted about $41 \%$ and $30 \%$ of the total respectively. Experience is important in determining the profit levels of farmers. The more the experience, the more farmers understand the farming systems, conditions, trends e.t.c.

Majority of the farmers (75.5\%) are small-scale farmers cultivating between 0-2 hectares while $15.6 \%$ and $8.9 \%$ cultivate between 3-4 and 5 hectares or more signifying the low productivity in the study area. 


\section{Profitability of Rice Production-:}

Table II shows the analysis of costs and returns. The result reveals that it is worthwhile to invest in rice production in the area since it yielded a profit margin of $\$ 16,977.65 / \mathrm{ha}$. This is because the fixed cost of rice production in the study area is negligible due to the fact that most farmers use inherited lands.

\section{Factor-Product Relationship-:}

Results of the regression analysis indicated that land, seed, hired labour, and fertilizer are the major determinants of output since they were statistically significant (Table III). Furthermore, these variables affect output positively which implies that an increase in the quantity of each will also increase output. Thus at $1 \%$ increase, farmland and fertilizer would increase output by 842.9 and 37.3 percent respectively. However, $79.6 \%$ of the variation in output is explained by the factor inputs used in the model.

\section{Marginal Productivity and Efficiency of Resource use-:}

Table IV reveals that comparison of the ratio of MVP to MFC shows resulting ratios to be greater than unity for land, seeds, hired labour, and fertilizer indicating that such inputs were underutilized. For other variables, chemicals and family labour, comparison of the ratio of MVP to MFC revealed a resulting ratio to be less than unity implying that chemicals and family labour were over utilized. In both cases, all the inputs were not utilized to optimum economic advantage. There is a need for adjustment in the MVP of all the inputs to ensure optimal utility. Gani and Omonona (2009) also observed that all the inputs used in irrigated maize production in Taraba State were not optimally utilized hence a need for adjustment in the MVP.

\section{Constraints to Rice Production-:}

The major problems militating against increased rice production in the area include poor road transportation network (46.7\%) to and from the rural areas. High cost of fertilizer (25.6\%) lack of storage facilities $(17.7 \%)$ weeds infestation and stray animals $(10.0 \%)$. These have affected the harvest of farmers in the study area as indicated on Table V.

\section{Conclusion}

The enterprise of rice production in Mubi-North region was revealed to be profitable. However, resources in the area were found not to be efficiently utilized hence not to optimum economic advantage. It therefore follows that increased rice production will be negatively affected. This has far reaching implication for food production. It is thus recommended that there is a need for adjustment in the marginal value product of all the inputs to ensure optimal use.

Table I.: Socio-economic characteristics of rice farmers

\begin{tabular}{|c|c|c|}
\hline Variable & Frequency & Percentage \\
\hline \multicolumn{3}{|l|}{ Age } \\
\hline Below 20yrs & 3 & 3 \\
\hline $21-30$ & 17 & 19 \\
\hline $31-40$ & 23 & 26 \\
\hline $41-50$ & 44 & 49 \\
\hline \multirow[t]{2}{*}{ Above 50} & 3 & 3 \\
\hline & 90 & 100 \\
\hline \multicolumn{3}{|l|}{ Gender } \\
\hline Male & 79 & 88 \\
\hline \multirow[t]{2}{*}{ Female } & 11 & 12 \\
\hline & 90 & 100 \\
\hline \multicolumn{3}{|l|}{ Literacy level } \\
\hline Non-formal education & 21 & 23.4 \\
\hline Primary & 29 & 32.2 \\
\hline Secondary & 31 & 34.4 \\
\hline \multirow[t]{2}{*}{ Tertiary } & 9 & 10.0 \\
\hline & 90 & 100 \\
\hline \multicolumn{3}{|l|}{ Years of experience } \\
\hline $1-5$ & 14 & 16 \\
\hline $6-10$ & 37 & 41 \\
\hline $11-15$ & 12 & 13 \\
\hline \multirow[t]{2}{*}{ Above 15} & 27 & 30 \\
\hline & 90 & 100 \\
\hline \multicolumn{3}{|l|}{ Farm size } \\
\hline Less than 1ha & 26 & 28.8 \\
\hline $1-2$ & 42 & 46.7 \\
\hline $3-4$ & 14 & 15.6 \\
\hline \multirow[t]{2}{*}{5 and above } & 08 & 08.9 \\
\hline & 90 & 100 \\
\hline
\end{tabular}


Table II: Average costs and returns of rice production.

\begin{tabular}{|l|l|}
\hline Inputs used & Costs ( $\mathbf{f} / \mathbf{h a})$ \\
\hline Fertilizer & $1,717,300$ \\
\hline Seeds & 347,022 \\
\hline Chemicals & 27,080 \\
\hline Transportation & 47,680 \\
\hline Storage & 16,865 \\
\hline Labour & 676,458 \\
\hline Empty bag & 325,310 \\
\hline Total Variable Cost (TVC) & $\mathbf{3 , 1 5 7 , 7 1 5 . 0 0}$ \\
\hline Total Revenue (TR) & $\mathbf{3 , 1 7 4 , 6 9 2 . 6 5}$ \\
\hline Gross Margin (TR-TVC) & $\mathbf{1 6 , 9 7 7 . 6 5}$ \\
\hline
\end{tabular}

Table III: Linear Production Function of Rice

\begin{tabular}{|l|l|l|}
\hline Factor inputs & Elasticity & t-ratio \\
\hline Land & $842.969^{* * *}$ & 2.737 \\
\hline Seed & $23.413^{*}$ & 1.963 \\
\hline Family Labour & 0.073 & 0.183 \\
\hline Hired Labour & $42.061^{* *}$ & 2.239 \\
\hline Fertilizer & $37.272^{* * *}$ & 4.417 \\
\hline Chemicals & 122.249 & 1.408 \\
\hline Constant & -1254.455 & -3.584 \\
\hline $\mathrm{R}^{2}$ & $\mathbf{0 . 7 9 6}$ & \\
\hline F-ratio & $\mathbf{5 3 . 9 8 2}$ & \\
\hline SE & $\mathbf{3 5 0 . 0 4 7}$ & \\
\hline
\end{tabular}

$* * *, * *$ and $*$ are significant at 1,5 , and $10 \%$ levels respectively

Table IV: Estimated resource use efficiency in rice production

\begin{tabular}{|l|l|l|l|l|}
\hline Resources & MPP & MVP & MFC & Efficiency level(r) \\
\hline Land & 842.969 & $17,251.51$ & $3,047.33$ & 5.65 \\
\hline Seeds & 23.413 & 880 & 64.01 & 13.75 \\
\hline Chemicals & 122.249 & 1.16 & 580 & 0.002 \\
\hline F. Labour & 0.073 & 0.003 & 0.01 & 0.30 \\
\hline H. Labour & 42.061 & 1280 & 165.33 & 7.74 \\
\hline Fertilizer & 37.272 & 124.36 & 35.00 & 3.55 \\
\hline
\end{tabular}

Table V: Problems encountered by the respondents

\begin{tabular}{|l|l|l|}
\hline Problems & Frequency & Percentage \\
\hline Poor transportation & 42 & 46.7 \\
\hline High cost of fertilizer & 23 & 25.6 \\
\hline Lack of storage facilities & 16 & 17.7 \\
\hline Weeds infestation and stray animals & 09 & 10 \\
\hline
\end{tabular}

\section{References}

[1] Adebayo, E. F. (2005): Resource use efficiency and multiple production objectives of diary pastoralists in Adamawa State. $2^{\text {nd }}$ Seminar paper, Department of Agricultural Economics, University of Ibadan Seminar Series.

[2] Adebayo, E. F. and J. I. Onu (1999): Economics of rice production in Yola North and South Local Government Areas. Nigerian Journal of Tropical Agriculture 1:15-20.

[3] Akande, T. (2002): An Overview of the Nigerian Rice Economy. The Nigerian Institute of Social and Economic Research (NISER), Ibadan Nigeria.

[4] Akpokodje, J., F. Lancon, and O. Ereanstin (2001): Nigeria's Rice Economy. A Project Report, the Nigerian Rice Economy in a Competitive World. Constraints, Opportunities and Strategic Choices. WARDS.

[5] David, C. (1992): Rice in Deep Water. 1st Edition, the Macmillan Press Limited. Eccleston place.

[6] Dogondaji, S. D. And K. M. Baba (2010): Income Distribution in Large Scale Irrigation Projects: A Case Study of Dry Season Rice Farmers at the Bakolori Irrigation Project, Zamfara State, Nigeria. A paper presented at the $24^{\text {th }}$ annual National Conference of the Farm Management of Nigeria held at the Adamawa State University, Mubi. 11-14 ${ }^{\text {th }}$ October 2010.

[7] Gani, B. S. And B. T. Omonona (2009): Resource use Efficiency among Small-scale Irrigated Maize Producers in Northern Taraba State of Nigeria. Journal of Human Ecology, 28(2): 113-119.

[8] IRRI (1997): IRRI Annual Report, International Rice Research Institute, Los Banos, Philippines. P34-42.

[9] Moses, J. D. And E. F. Adebayo (2007): Profitability of Rain-fed Rice Production in Ganye Local Government Area, Adamawa State, Nigeria. Nigerian Journal of Tropical Agriculture vol. 9: 146-153.

[10] Okoruwa, V. O. (1994): The Economics of Agro-pastoral Production systems in Derived Savannah of Oyo State, Nigeria. An unpublished Ph.D Thesis, Department of Agricultural Economics, University of Ibadan, Nigeria.

[11] Shehu, J. F., S. I. Mshelia, A. K. Tashkalma, and B. H. Gabdo (2009): Economics of Small-scale Rain-fed Upland Rice Production in Adamawa State. African Journal of Agricultural Research and Development, 2(1):28-33.

[12] USDA (2003): Rice Yearbook, Market and Trade Economics Division, Economics Research Service. 